\title{
Green Accounting: Understanding of Accounting Students
}

\author{
Shofiana Hanifa ${ }^{1}$, Abdul Kahar ${ }^{2}$ \\ School Of Accounting Faculty of Economics, Central Sulawesi Province 94118, Indonesia \\ Intuitive_Shofia@yahoo.com ${ }^{1}$, kaharabdu1987@gmail.com²
}

\begin{abstract}
Increasing of society awareness supported by unlimited information access nowadays causing environmental issues always take widespread attention from any holder. Green accounting is an answer from accounting towards environment degradation issues which caused by business activities. In this terms, accounting students have a preferential position. They have been educated on accounting and they are university students, who also considered as idealism agent of change. They will determining how accounting in future. The aim of this research is to get a comprehension perspective of accounting students toward green accounting topic based on their background study as university students for four years or more. Data collected from four students and analyzed used discourse analysis method. The result is accounting students consider that green accounting is very important to learn and environmental awareness of an accountant also can indirectly encouraged company to implement green accounting method. It shows that accounting students have high concern about their profession to influence shareholders.
\end{abstract}

Keyword : Green Accounting, Environmental Accounting, Discourse Analysis

\section{Introduction}

Basically, humans being develop with nature. They really realize that the nature cannot be separated with them. They learn to survive, take what they need without damaging the nature and comprehend their existing is one of subsystems from some subsystems in big environment system.

While industrial revolution is begun on $18^{\text {th }}$ century, people start to neglect the nature. It seems like they found "new god" to make their life easier and more practice. For the people, the nature is not friend anymore, even they regard it as obstacle in civilization progress. So that they begin to damage the earth.

Schimedheiny (1995) claims that the condition like that is the consequence from misunderstandings people about environment. The misunderstandings are:

1. The opinion about progress of industry and sustainable construction are not related each other.
2. The judgment about sustainable construction as future needs, even it sacrifices the needs in short period.

The old view about relation between industrial world and environment still hold. Both environment protection and ability of producing profit are two things which are always contradictory. For industry world, to make profitable ability better is looked as decreasing the profitable ability itself, but for consumer, it will increase cost. In fact, the profitable ability requires usage and destruction environment.

Conventional accounting does not have any attention to transactions which have quality like non reciprocal transaction. The conventional accounting only records the transaction on both sides (reciprocal transaction), while green accounting records transaction which is not on both sides, such as pollution, environment decay, or negative effect from factory. These limitations will be felt if the accounting system is related to operational business connected with environment management. Costs related to the environment are management waste cost, disposal cost, installation disposal, license cost, the cost for third party and etc. On the conventional accounting, these costs are known as general cost item for the factory (overhead cost). Inappropriateness of the costs grouping is influenced when the factory should take a financial decision until the factory management decides policy that is not appropriate.

On Accounting Department Tadulako University, there are two lectures which talk about business problem and environment; they are Kajian Lingkungan Hidup (KLH) and Etika Bisnis Profesi. Both of these lectures are given to the accounting students in order to make the students have awareness about environment before they enter accounting world that has so many digits. 
Moreover, when they have a profession in accounting field and everything can be measured by nominal, it will never be happened uncareness on the environment around them.

Students have an important social role because it is considered as the young men who usually feisty, passionate, full of initiative and ideas for the sake of progress and changes for better life. Moreover, Indonesia is a country with historical records engraved gold ink on the role of students in the overthrow of authoritarian government.

Students are a status which carried by a person because of his relationship with the university whom expected to be candidates for intellectual. Including the accounting students who will likely plunge in the areas of work in accordance with current studies focus of study. At that time, they could give more impacting the result of their education to the world of accounting in particular and business in general. Therefore, it is not an exaggeration to say that the current accounting students is the forerunner of the generation that will change the world in the future accounting.

\section{Research Purposes}

The aim of this research is to get an understanding of accounting students toward green accounting topic based on their background study as university students.

\section{Literatur Overview}

Bell and Lehman (1999) defining green accounting as:

"Green accounting is one of the contemporary concepts in accounting that support the green movement in the company or organization by recognizing, quantifying, measuring and disclosing the contribution of the environment to the business process".

In other word, green accounting is accounting which identify, measure and group the costs that related to environment, which for programs that purpose to reclamate, to preserving and to greening the environment or costs which caused by environmental's sacrifice for business producing.

There are four reasons why the emphasis on environmental issues increasingly significant performed. First, the larger the size of the company. Second, growing number of activists and NGO. Environmental NGO has grown rapidly throughout the world, including Indonesia. Third, the reputation and image of the company. Companies today realize that reputation, brand, and the image of the company is a strategic issue that is of high value and should be protected. Fourth, advances in communications technology (Darwin, 2007).

Environmental costs by Schaltegger (2000) is divided into two, namely the company's internal costs and external costs. Environmental costs that are internal company include waste handling costs, training costs associated with environmental problems, costs associated with environmental labeling, the cost of the necessary permits, environmental certification costs, and so on. External environmental costs include the cost of depletion of natural resources, the cost of noise pollution, water pollution costs, and so on.

Gunawan (2012) writes that the successful implementation of the environmental costs not only depend on the accuracy in classifying all costs made the company but the ability of the company and the reasonableness of accounting data in suppressing the environmental impact of the activities of the company. By minimizing the environmental issues, the company can improve efficiency from a cost standpoint (environmental cost) and the benefits or effects (economic benefits). Implementation of environmental accounting by various companies can produce a quantitative assessment of the costs and impact on the performance of environmental protection and the quality of the company's financial performance.

Lohmann (2009) suggest his opinion about the importance of green accounting:

Environmental accounting is supposed to address Reviews such crises in two ways. First, it makes environmental crises more visible to decision-makers, by classifying 
them in a way that makes explicit preexisting equivalences or quantifiable relationships with commodities and other economic objects. Second, environmental accounting environmental helps transform objects into commercial 'goods and services' Whose value can be 'discovered' in markets themselves. Trade itself Becomes comparative valuation and environmentalist action.

Based on the statement above, green accounting role is to increasing the aware of environmental issues by stakeholders and decision makers by presenting the relationship between environmental and economic objects quantitatively. In addition, another role of green accounting is to provide a commercial price for environmental factors so that its value can be found. Scmedheiny (1995) argues that if the price of natural resources can not be determined, then the user will tend to be inefficient and environmental pollution will increase.

According Pramanik, et.al in Astuti (2012), the purpose of the development of environmental accounting is to encourage accountability and increase transparency environmental entities; assist entities in establishing strategies to respond to environmental issues in the context of the entity relationship with the community and especially with groups of activists or a pressure groups related to environmental issues, give more positive image so that the entity can obtain funds from "green" groups and individuals, encourage consumers to buy green products so that the entity has a more competitive marketing advantage compared to entities that do not perform disclosure, demonstrate commitment to the business entity environmental improvement, prevent negative public opinion in view that generally, company which strives on risk environmentally friendly risk will accept the challenge of the community.

Accountants and auditors are not directly involved in the prevention of environmental impacts caused by industrial activities. However, their professional expertise could have a huge impact on the company's management of policy and the decision makers. Harahap (2011) considers that the auditors as inspector of financial statements have a social contract with the people to keep their interest from a variety of adverse action.

\section{Research Method}

This study used a qualitative paradigm of Van Dijk discourse analysis method. Discourse analysis method chosen because of its focus on language use practices, especially the politics of language. Because language is a central aspect of the description of a subject and through language, ideology absorbed in it. Discourse is a hidden purpose of the investigation of the subject which sets out a statement (Eriyanto, 2001). Since the purpose of this study is to explore the deepest understanding of a discourse, it is appropriate discourse analysis to reveal more detail. Disclosure done by putting researcher in the position of the narrator with the interpretation follows the structure of the narrator's meaning with top bottom processing.

Through the model, Van Dijk said that a discourse consists of a variety of structures/levels, which each of parts support each other. Van Dijk divide it into three levels; (1) Macro structure, this is a global meaning/general of a text, that can be observed by looking at the topic of a text, (2) Superstructure is a framework of a text, how the structure and elements of discourse that are arranged in the text as a whole, (3) Micro structure is the meaning that can be observed by analyzing the words, sentences, propositions, clause, prafrase used, and so on.

\section{Discussion}

Humans are not the only creatures that live on this earth. They are a living of many living beings whose life is dependent on the same nature as human beings. In fact, nature provides the main requirement for humans life, that is to breathe. The process of respiration requires oxygen that obtained from the photosynthesis of plants. Oxygen is an infinite resource whose existence depends on vegetation. When the plant is damaged, then oxygen source would less. If it's ongoing, then the situation could threaten the system's life on this earth. This fact are realized by the first narrator who argued: 
Narrator I: "Because if there is no environment, we can not breathe".

The definition of the natural environment by KBBI are: (1) The around state (condition, strength) which affect the development and behavior of organisms. According to Law No. 4 of 1982 on the Main Principles of Environmental Management, the Constitution No. 10 of 1992 on Population Development and Family Welfare Development, and the Constitution No. 23 of 1997 on Environmental Management, the environment is definied as unity of space with all things, power, circumstances and living things, including humans, and behavior that affect living condition and human welfare and other living organisms. In $\mathrm{KBBI}^{1}$, another definition of the environment is added namely: the outside environment of an organism consisting of living organisms such as plants, animals and humans.

Based on some definition of the natural environment and the environment above, it can be deduced that all living things, including humans, is strongly influenced by the condition and strength around him. It is agreed by the third and fourth narrator who explain that environmental conditions can affect the work, including the work of an accountant.

Narrator III: "...because when the environment is not good and supported by the accountant mental condition whe $e^{1}$ making a bookkeeping, of course it will affects, it will makes more pressure".

Narrator IV: "...because the accountant was no other than a human must. Human being is closely connected with nature. Like in health, then in taking any decision situation, sometimes accountants often influenced by the environment. For example, in a state of fatigue, tired due to taking care of his business all day and then when he faced a problem, and when he will make a decision but looking at the filthy and chaotic environment, it will automatically affect the mind, and it will have a negative impact. But when he was tired, but seeing the

\footnotetext{
${ }^{1} \mathrm{KBBI}$ is an acronym of Kamus Besar Bahasa Indonesia (Great Dictionary of Indonesian)
}

environment which neat, clean, fragrant, it will automatically also make the mind more clearly. It will affect an accountant, in terms of decision-making".

Accountant's accounting decisions related to how he decided classification of costs. There should be no error in the decision, because the recording error means the financial statements produced will not fit with the reality, and it will nullify the information function of the financial statements. While the narrator above take the viewpoint of the environmental comfort which are the external factors of accountant, then first narrator make a logical from internal self of accountant perspective as spoken as follows:

Narrator I: "It's definitely have effect. For example, accountant who care about environment, the cost will increase because there are environmental costs. Meanwhile, if accountants do not care about the environment, the costs will be reduced. So, it's about how he can get a high profit and he can also have higher salary. That is in my opinion anyway".

Internal factors of the accountant that intended by Narrator I is a sense of environmental awareness and economic motives to get a high salary. Three discourses above will also described as follows:

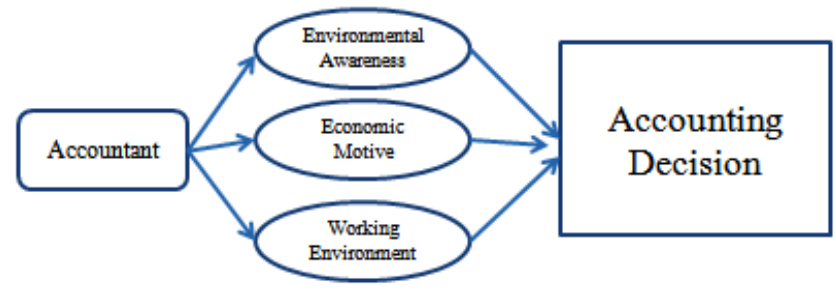

Source: Data Processed (2015)

Picture 5.1

How Environmental Awareness of An Accountant Influence His Accounting Decision

Environmental awareness is become more important due to financial accounting standards that became a reference for the world of accounting has a basic framework that presents the basic concepts of the preparation and presentation of financial statements, which is commonly known as the Framework for the Preparation and 
Presentation of Financial Statements. In the framework, there is a basic assumption of the preparation of the financial statements of an entity, that are the basis of accrual and going concern assumption or it commonly called the principle of going concern

Going concern principle assumes that a business will continue forever so that the financial statements are prepared is a temporary view in the middle of the sustainability of how the position of the business at the present time. Judging from another perspective, the going concern principle is an expectation that the business is forever will continue to live and make a profit as the main goal of business activities.

But apparently, hope as it is does not always come true. De Gaus (2003) in his book "The Living Company" wrote that one-third of the companies listed in the Fortune 500 in 1970 had disappeared in 1993 due to various reasons and only about thirty companies which persist for at least a hundred years. De Gaus also revealed the results of his research on the four charracters of the companies that can survive in a very long period of time, it is namely: (1) sensitivity to the world around, (2) Awareness of identity, (3) Tolerance to new ideas, and (4) Conservative in financial terms. Thus, it can be summarized from the four properties that if you want to survive in the rigors of the business world, an entity must be flexible, sensitive and attentive to trends in society.

In relation with it, the environment is an issue that never missed widespread attention from many holders. Narrators IV mentions a case related to the business and environmental damage, namely:

Narrator IV: "It's like Lapindo ${ }^{2}$, it was because he hurt a lot of people in the vicinity. What do we see they now? Company is lost. Even unable to pay debts to the people who feel the loss caused by the Lapindo".

And as told by Narrator IV above, the reason of the PT Lapindo Brantas Minerak bankruptcy caused by the large amount of compensation that must to be paid to the victims of Lapindo mud. This fact is certainly a thing that can not be underestimated, especially when looking at increasing of public environmental awareness lately. Companies that can not adapt to these demands will certainly lose customers who switch to another company's products that have environmentally friendly business management. Environmentally friendly can be an intangible capital for corporate excellence. This is about creating a good image in order to create a good relationship between the company and the public, in which the relationship can support business continuity, as stated by the narrator III:

Narrator III: "...where there is a healthy and clean environment, it will also reflect the sustainability of the company itself".

Good image is one form of intangible assets, as goodwill. The definition of goodwill is the advantages and certain privileges owned by the company, for which the company was valued more by the other holders. When goodwill held high, it will benefit the company in the stock market because it is considered by investors as an entity that looks promising. While the good image is about good impression of a company in the eyes of society.

Narrator I: "Accountant caring about environment, it will influence the development of the company. There are direct relation. If accountant care about the environment, there are costs incurred, there are $\operatorname{CSR}^{3}$ program to the surrounding society. It's about how the company is well known. What is produced can be sold in the market".

The narrator II found that a company which has a good impression on environmental issues can sell more of their products to the market than the companies that have problems with the environment. That is named as competitive advantage. Based on discourse that expressed by the narrators, then the relationship between the companies that care about the environment,

2 Lapindo is one company in Indonesia which have environmental problem.

${ }^{3}$ CSR is an acronym of Corporate Social Responsibility 
accounting and business continuity can be described as follows:

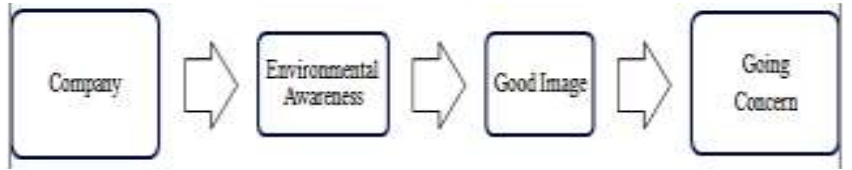

Source : Data Processed (2015)

Picture 5.2

The Relation Of Environmental Awareness And Going Concerning

Accounting is one part of a company that is working on backstage in the financial affairs that be the most important and the main purpose of business activity. Accountants are humans, not machines that can think. Therefore, the accountant is also influenced by personality, principles, and the charracters that make up hisself. Denied or not, those things related also to the his work which is to identify, analyze, and classify the costs to be arranged into a language that can be understood by all parties.

Could the principles of environmental concerns an accountant could affect the company to be more concerned with the environment or implement green accounting? The answer turned out to be different views from different angles. The first view, it's see accountants from authority of the profession scope. Because accountants working 'behind the scenes' and not directly related to the external environment and also not a formulator and policy makers, the environmental concerns of an accountant will not be able to influence the company to implement green accounting, or at least to be more concerned with the environment. This view was formulated by Narrators II as follows:

Narrator II: "Indirectly related. Because not accountants who should be responsible. But one of their job is to record. So, suppose there were casualties as a result of environmental damage done by the company. It makes the company must bear the cost of the hospital, now it should be noted. Accountant is the one who record that. So it is, the relationship between the accountant with the environment. It's practically indirect. We're part of accounting, our task just to record".

The second view see accounting as a social individual who does not loose its interaction with other individuals. That's why accountants who have high environmental awareness is considered to encourage other individuals who work in the company to implement green accounting. This view was expressed by the narrator I, namely:

Narrator I: "It can be. He's an accountant, accountant has a financial decision, he manage the finances. He can told the manager "We have to care about the environment".

As individuals, accountants who have high environmental awareness can also transmit the positive principal throughout the corporate as follows:

Narrator III: "It will have an effect. Because when we love the environment, we will also love the work atmosphere automatically, the work environment, and consciously or unconsciously it will affect the people who exist in our work environment".

But that second perspective is have certain conditions, it is how much environmental awareness of an accountant till he could embody that love into actions that effects on the environment. This requirement raised by Narrator IV, namely:

Narrator IV: "I think it is so unlikely for a person who care about environment can affect his surroundings, toward companies or even the employees in the company. Because why? He's just an accountant. Concerning itself must be created by ourselves. Not just from one person. If only one person who has the care, i think it is very unlikely be able to affect the people around him who did not have a high sense of caring environment. Except when he might be able to allure them, or if his concern for the environment was very high, very great love for the environment then he gives effect to the environment or to the employees there, it may be works". 
And it is reinforced by the opinion of the narrator II:

Narrator II: "Some can be influential, some are not. Some are concerned with the environment but can not affect, depending on the person hisself".

Accountant is a sub-system of various other sub-systems within a large system named company whose function is to support each other in order to achieve mutual benefit. Even when take a see from the humans nature as a social being which interdependent each other, then it is possible that the accountant, as the word Narrators IV "just an accountant", can give the effect of environmental awareness to other people who work in the company until finally the influence extends to the advanced management level authorities as policy makers. Based on the discourse of the narrators on this topic before, the relationship between accountants who care about the environment with the implementation of green accounting by the company can be illustrated as follows:

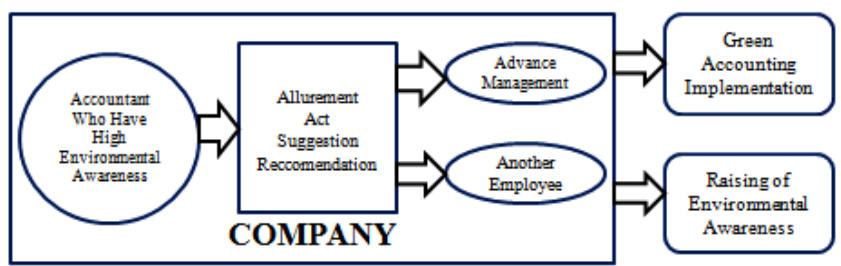

Source: Data Processed (2015)

Picture 5.3

\section{How Accountant Can Influence His Company To Implement Green Accounting Indirectly}

No matter the state of the world of work that lies ahead there, environmental awareness owned by current accounting students could be a description of their attitude in the future. One point that can be used to see how the environmental concerns that accounting students is to consider their feelings about the problems of environmental damage caused by business activities that happening.

Narrator I: "Yeah, i feel sorry for the people who take the effect. So if you want to set up a company there AMDAL . AMDAL is functioned to see how the company's activities affect on the surrounding environment. Whether they harmed or benefited to environment, it's all there in the AMDAL, which I know".

Not only criticize, Narrators I also knows about the environmental damage prevention solutions that can be optimized for the benefit of the future. For Narrators II, there was anger and emotion that is so evident in every syllable that shows how wroth Narrators II is toward the environmentally destructive act:

Narrator II: "I think the company should be held more responsibilities to the surrounding environment. Especially if the company is directly related to the environment. If it is damaged, the companies should be responsible. If damaged, they must repaired it. Companies must have the initiative or have a way to improve the environment that has been undermined. That is if it is damaged. Then if not, the company should be able to keep the surrounding environment so that it will not broken".

Narrators II emphasizing that the company should concerned to bear the guilt and full responsibility for the environmental damage as a result of their business activities which are not environmentally friendly.

Narrator III: "...as far as possible reduce damage to the environment. Because that damage will impact on the business activity itself. And the people affected by the business that bear damage of the environment mostly. Like bad image, so it is not a good image in the eyes of society".

Narrator IV: "In my opinion, it is not responsible, the company that did those. Because why? Because indirectly, they were already harming the surrounding environment. Not only the company itself that would be affected. For example, when the company's loss, the loss is not covered by

\footnotetext{
4 AMDAL is Indonesian acronym of Analysis of Environmental Impact
} 
their own, but by the surrounding environment".

Based on the statements above, it was concluded that the narrators have high environmental awareness for all of the same opinion: that a good business was not only the 'hit and run' pursue its own benefit, but also help improve the quality of life around it.

Associated with green accounting, researchers dug basic perception that embedded in their minds about the concept of green accounting. This perception is obtained by asking the narrator to mention what's in their heads when they heard two separate words; "green" and "accounting".

Narrator I: "Maintenance. Utilization. Planting. How do we plant a tree, it's certainly have cost. Here, the role of accounting for how to take its cost into account, approximately how long it grows, the costs incurred in the back, from watering, fertilizing, that's a lot of costs".

Narrator II: "CSR".

Narrator IV: "When I heard these two sentences, that is in my mind is money or costs. Why? Because for accountant to improve the environment it would need cost".

All three narrators associate the two words above of the costs incurred by the company forestry programs and environmental conservation as well as from the management to organize and plan the implementation of the program. Another opinion came from the narrator III who associate the word "green" and "accounting" as the room where the work of an accountant, green, clean and comfortable.

Narrator III: "Workspace. Work place".

After digging the perspective of forming the basis of perception, researchers asked narrators to explain their understanding of green accounting:

Narrator I: "It's about the manufacturing company.It is within cost of production".
Narrator II: "It is same like environmental accounting, right? Is CSR within it? Yes, CSR. There are also environmental responsibility in".

Narrator III: "I think it still in relation to the environment, huh?".

Narrator IV: "According to me, the green accounting or environmental accounting is accounting that including the cost of environmental hygiene or environmental maintenance costs within its costs. So, when there are financial statements, or income statement, he put the environmental costs to reduce the revenue".

When described, the perspectives that form the basis of an understanding of the narrators on green accounting is as follows:

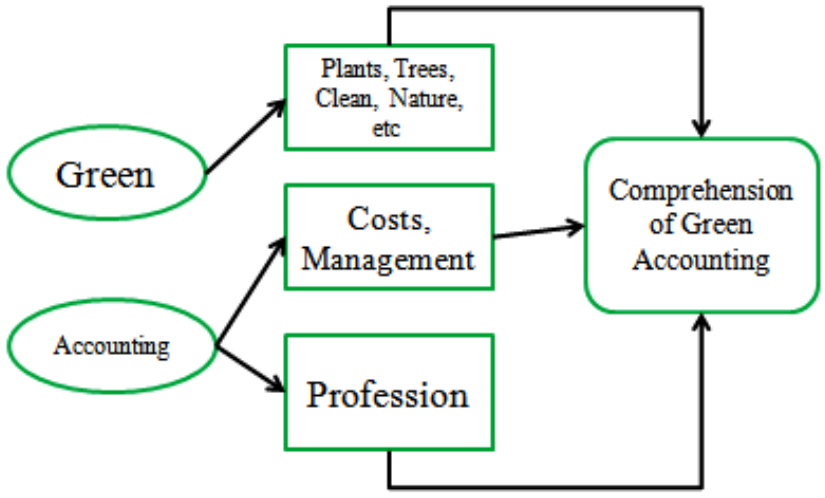

Source: Data Processed (2015)

Picture 5.4

\section{Accounting Students Comprehension Toward Green Accounting}

Narrators discourses above shows that accounting students actually understand the meaning of green accounting that explore and classify the costs associated with the program and policy to preserve nature. However, the understanding still formed on the surface. Because the real green accounting also quantify the environment sacrifice caused by the activities of companies such as air pollution, water pollution, noise pollution, degradation of soil fertility and others.

To explore green accounting further, the main road that can be achieved is through higher education at a university that has a major in accounting. Because the university as the highest education level have heavier mission than primary, 
intermediate or advanced education. Aim of Higher Education According to the PP 60 of 1999 on Higher Education (PT), Article 2 is:

(1) Preparing students to become members of the community who have the academic ability and/or professionals who can implement, develop and/or enrich the science, technology and/or art.

(2) Develop and disseminate science, technology and/or art and trying to use to improve people's lives and enrich the national culture.

In addition of studying accounting expertise, green accounting also focuses on moral and ethics that must be imparted to the students of accounting so that when they go into the world of professional work later on, they will not be carried away by the flow of capitalism that focuses entirely on improving profit. Accounting students who received instruction on environmental awareness in college will generate future accountants who care about the environment as it is described as follows:

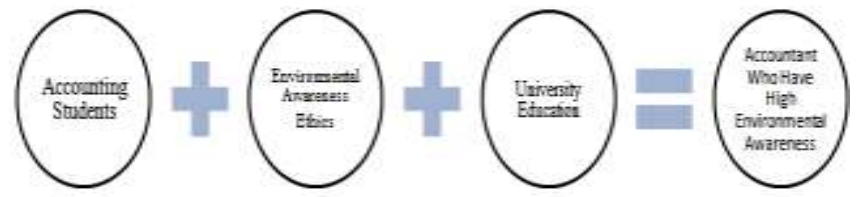

Source: Data Processed (2015)

Picture 5.5

\section{How Accounting Education Can Make A Accountant Who Have High Environmental Awareness}

The discourses above is in accordance with one of the goals of higher education that sought the use of science to improve people's lives. The goal has been fully realized by the narrators who agreed that green accounting is an important topic to be studied, based on the following statement:

Narrator II: "...it is important so that we can know, who do not know will get to know. It's very important to be studied further. Who studied at the campus's only KLH ${ }^{5}$. We learned only very few of environmental accounting in it".

\footnotetext{
${ }^{5} \mathrm{KLH}$ is an acronim of Kajian Lingkungan Hidup (Study of Environmental), one of lecture study on Accounting Department Tadulako University.
}

Narrator III: "...because in addition to our business is not merely thinking of our own interests but also for greening the environment".

Narrator IV: "Of course, very important. In order accountant as one important part of the business is realize that pursue profit only regardless of the environment it is a big wrong".

Accountant profession is in challenged to show their "claw" in the middle of business world which in nervouse as effect due to widespread thoughtfulness towards environmental damaging. In theory, green accounting is an answer to reduce the problem. What is left is how accountant as the accounting agent implement it to bring the goodness for all holders and environment as well.

\section{Conclusions}

Based on the analysis above, it can be concluded that:

1. From the perspective of moral and ethics, an accountant should have the environmental awareness.

2. Environmental awareness of an accountant influence their accounting work decision.

3. Environmental awareness of an accountant also can indirectly encouraged company to implement green accounting method.

4. The narrators considers that green accounting is an important issue in the world of accounting.

\section{References}

Astuti, Neni. (2012). Mengenal Green Accounting. PERMANA. Vol. IV No.1 August 2012. Tegal.

Darwin, Ali. (2007). Jalan Panjang Audit Lingkungan. Magazine of Ikatan Akuntansi Indonesia (IAI), 3 ,9-11.

De Geus, Aria. (1997).The Living Company.Harvard Business School Press. 
Djajasudarma, T. Fatimah. (2006) .Wacana:

Pemahaman dan Hubungan Antar Unsur.PT.

Refika Aditama.Bandung

Eriyanto. (2001). Analisis Wacana: Pengantar Analisis Teks Media. PT LKiS Pelangi Aksara.

Gunawan, Eric. (2012). Tinjauan Teoritis Biaya Lingkungan Terhadap Kualitas Produk Dan Konsekuensinya Terhadap Keunggulan Kompetitif Perusahaan. Journal of Accounting Student. 1, 2. Unika Widya Mandala. Surabaya.

Harahap, Sofyan S. (2011). Etika, Kapitalisme, dan Profesi Akuntansi. Magazine of Accounting, Auditing and Information Research.

Lohmann, Larry. 2009. Toward A Different Debate In Environmental Accounting:The cases Of Carbon And Cost-Benefit. Accounting, Organizations and Society 34 (2009) 499-534.

Rossje. 2006. Akuntansi Lingkungan: Sebuah Perspektif. Trisakti University. Jakarta.

Schaltegger, S., \& Burritt, R.2000. Contemporary Environmental Accounting. Greenleaf Publishing Limited.

Schmidheiny, Stephan. 1995.Mengubah Haluan Industri Berwawasan Lingkungan..ITB Publisher. Bandung.

http://kangdoel90.blogspot.com/2010/03/pro-dankontra-terhadap-penolakan.html http://masbagyo.net/2014/02/18/the-livingcompany-agar-perusahaan-berumur-panjang/ http://nasional.kontan.co.id/news/724-juta-orangindonesia-adalah-pengangguran

http://pengolahansampah2.blogspot.com/2013/11/ pengertian-lingkungan-dan-macam-macam.html http://www.gunadarma.ac.id/en/page/sistempendidikan-tinggi.html 